\title{
UJI AKTIVITAS ANTIOKSIDAN EKSTRAK DAN FRAKSI RIMPANG TEMU KUNCI (Boesenbergia pandurata) DENGAN METODE 1,1-DIFENIL-2- PIKRILHIDRAZIL (DPPH)
}

\author{
Barly Sugara, Adam M. Ramadhan, Arsyik Ibrahim \\ Laboratorium Penelitian dan Pengembangan FARMAKA TROPIS, Fakultas Farmasi, \\ Universitas Mulawarman, Samarinda, Kalimantan Timur \\ Email: barly.ff011@gmail.com
}

\begin{abstract}
ABSTRAK
Tujuan dari penelitian ini adalah untuk menentukan nilai $\mathrm{IC}_{50}$ ekstrak etanol dan fraksi (nheksan dan etil asetat) dari ekstrak rimpang temu kunci. Penentuan potensi aktivitas antioksidan dilakukan dengan metode DPPH dan besarnya korelasi dihitung dengan persamaan regresi. Hasil penelitian pengujian aktivitas antioksidan menunjukkan, ekstrak etanol rimpang temu kunci diperoleh nilai $\mathrm{IC}_{50}$ sebesar 112,342 ppm. Aktivitas antioksidan dari fraksi n-heksana diperoleh nilai $\mathrm{IC}_{50}$ sebesar 164,006 ppm dan aktivitas antioksidan dari fraksi etil asetat diperoleh nilai $\mathrm{IC}_{50}$ sebesar 162,224 ppm.
\end{abstract}

Kata kunci : Aktivitas antioksidan, $\mathrm{DPPH}, \mathrm{IC}_{50}$, Boesenbergia pandurata

\begin{abstract}
The aim of this research were determined $I C_{50}$ value of ethanol extract and its fraction ( $n$ hexane and ethyl acetate) from ethanol extract of Boesenbergia pandurata rhizome. DPPH methode was used to determine the radical scavenging activity and the correlation was measured using a linear regretion equation. The result of this research showed that ethanol extract was obtained IC $C_{50}$ value is $112,342 \mathrm{ppm}$. All of the fractioned was tested its antioxidant activity, $n$-hexane and ethyl acetate fraction showed antioxidant activity with IC50 values of 164,006 and 162,224 ppm.
\end{abstract}

Key words: Antioxidant Activity, DPPH, IC50, Boesenbergia pandurata.

\section{PENDAHULUAN}

Radikal bebas diartikan sebagai molekul yang mempunyai satu atau lebih elektron yang tidak berpasangan di orbit luarnya sehingga relatif tidak stabil. Untuk mendapatkan kestabilannya, molekul yang bersifat reaktif tersebut mencari pasangan elektronnya, sehingga disebut juga sebagai Reactive Oxygen Species (Pinell SR dalam Ardie, 2011). Senyawa yang dapat menstabilkan radikal bebas adalah antioksidan. Senyawa ini dapat menghambat reaksi berantai dari pembentukan radikal bebas (Hudson, 1990). Meningkatnya penelitian dalam menemukan antioksidan alami untuk kosmetik, makanan, atau obat-obatan untuk menggantikan antioksidan sintesis, disebabkan penggunaan antioksidan sintesis telah dibatasi karena efek samping yang dimiliki. Selain itu antioksidan alami lebih dipertimbangkan karena lebih aman, stabil, dan efek antioksidan yang lebih baik (Zheng et al., 2001).

Antioksidan merupakan senyawa yang dapat menghambat reaksi oksidasi, dengan mengikat radikal bebas dan molekul yang sangat reaktif. Secara biologis, pengertian antioksidan adalah senyawa yang mampu menangkal atau meredam dampak negatif 
oksidan dalam tubuh. Antioksidan bekerja dengan cara mendonorkan satu elektronnya kepada senyawa yang bersifat oksidan sehingga aktivitas senyawa oksidan tersebut bisa dihambat (Winarsih, 2007).

Rimpang temu kunci merupakan salah satu rimpang yang banyak digunakan sebagai obat tradisional oleh masyarakat sebagai peluruh dahak atau untuk menanggulangi batuk, penambah nafsu makan (Syamsuhidayat dan Hutapea, 1991). Ekstrak etanol rimpang temu kunci diketahui memiliki kandungan utama senyawa golongan flavonoid dan minyak atsiri. Telah banyak senyawa-senyawa dari golongan tersebut yang dilaporkan sebagai antioksidan alami yang potensial (Buhler dan Miranda, 2000). Sehingga peneliian ini untuk mengungkap daya antioksidan ekstrak dan fraksi dari rimpang temu kunci.

\section{METODE PENELITIAN}

\section{Bahan}

Bahan yang digunakan dalam penelitian ini adalah: temu kunci (Boesenbergia pandurata) yang diperoleh dari Samarinda, Kalimantan Timur, DPPH (1,1- difenil-2-pikrilhidrazil), etil asetat, etanol 96\%, kloroform, metanol, n-heksan, $\mathrm{H}_{2} \mathrm{SO}_{4}$ pekat, $\mathrm{FeCl}_{3}, \mathrm{HCl} 2 \%$, asam asetat anhidrat, reagen dragendorf, reagen meyer, serbuk $\mathrm{Mg}$, dan $\mathrm{HCl}$ pekat.

\section{Peralatan}

Alat yang digunakan dalam penelitian ini adalah: almari pengering, corong Buchner, vacuum rotary evaporator, neraca analitik, spektrofotometer UV-VIS (Halo Db-20S UVVIS by Dynamica), mikropipet $100-1000 \mu \mathrm{L}$, blue tip, dan alat-alat gelas yang lazim digunakan di laboratorium analisis.

\section{Prosedur Penelitian}

\section{Pembuatan simplisia}

Sampel temu kunci yang telah dikumpulkan disortir kemudian dibersihkan dan ditimbang beratnya sebanyak $5 \mathrm{~kg}$, kemudian dirajang kecil-kecil dan dikeringkan menggunakan oven hingga diperoleh simplisia temu kunci kering. Kemudian ditimbang berat keringnya yaitu diperoleh 1334 gram dan dilakukan penghalusan menjadi serbuk simplisia.

\section{Pembuatan ekstrak}

Potongan kecil simplisia sebanyak 750 gram diekstraksi dengan menggunakan metode maserasi yaitu dengan cara merendam seluruh bagian serbuk kering dengan pelarut etanol 96\%. Dari hasil ekstraksi tersebut diperoleh residu dan larutan ekstrak temu kunci, kemudian disaring ampasnya dan disisihkan, bagian ekstrak cair hasil maserasi di diuapkan dengan menggunakan rotary evaporator pada suhu $30-40{ }^{\circ} \mathrm{C}$ hingga diperoleh ekstrak kental. Sisa pelarut selanjutnya diuapkan di atas water bath untuk memperoleh ekstrak kering.

\section{Penentuan rendemen}

Ditimbang temu kunci segar, temu kunci yang telah dikeringkan (simplisia), dan ekstrak etanol $96 \%$ hasil maserasi. Selanjutnya, dicatat dan dihitung jumlah rendemen sesuai dengan rumus perhitungan rendemen ekstrak yaitu berat ekstrak (g) dibagi dengan berat sampel kering sebelum ekstraksi (g) dikali 100\%, sehingga diperoleh nilai persen (\%) rendemen. 


\section{Identifikasi Golongan Metabolit Sekunder}

\section{Alkaloid.}

Larutan ekstrak dibagi menjadi 2 bagian dan ditambahkan $\mathrm{HCl} 2 \%$ lalu pereaksi Dragendorff sebanyak 3 tetes dan bagian lainnya ditambahkan pereaksi Mayer sebanyak 3 tetes. Terbentuknya endapan jingga pada tabung kedua dan endapan putih hingga kekuningan pada tabung ketiga menunjukkan adanya alkaloid

\section{Flavonoid.}

Dilarutkan ekstrak dan dipanaskan selama lima menit di dalam tabung reaksi. Selanjutnya ditambahkan $0.2 \mathrm{~g}$ bubuk $\mathrm{Mg}$, kemudian ditambahkan $\mathrm{HCl}$ pekat, hasil positif ditunjukkan dengan timbulnya warna merah tua.

\section{Polifenol.}

Identifikasi senyawa polifenol dengan menggunakan larutan besi (III) klorida 10\%, jika terjadi warna biru tua, biru kehitaman atau hitam kehijauan menunjukkan adanya senyawa polifenol dan tanin

\section{Steroid.}

Identifikasi senyawa steroid dengan menambahkan larutan ekstrak dengan kloroform lalu ditambahkan dengan asam asetat anhidrat. Selanjutnya campuran kedua larutan ini ditetesi asam sulfat pekat. Bila terbentuk warna hijau kebiruan menunjukkan adanya sterol. Jika hasil yang diperoleh berupa cincin kecokelatan atau violet pada perbatasan dua pelarut, menunjukkan adanya triterpenoid.

\section{Penentuan aktivitas antioksidan secara kuantitatif dengan metode DPPH}

Larutan DPPH $40 \mu \mathrm{g} / \mathrm{mL}$ dibuat dengan melarutkan $4 \mathrm{mg}$ serbuk DPPH dalam metanol. pada labu takar 100,0 mL, kemudian divorteks. Ekstrak etanol temu kunci dilarutkan dalam metanol dalam konsentrasi $0,1 \% \mathrm{~b} / \mathrm{v}$ dan dilakukan seri pengenceran hingga diperoleh konsentrasi $20 \mu \mathrm{g} / \mathrm{mL}, 40 \mu \mathrm{g} / \mathrm{mL}, 60 \mu \mathrm{g} / \mathrm{mL}, 80 \mu \mathrm{g} / \mathrm{mL}, 100 \mu \mathrm{g} / \mathrm{mL}, 120 \mu \mathrm{g} / \mathrm{mL}$, dan $140 \mu \mathrm{g} / \mathrm{mL}$. Sebanyak 2,0 mL sampel uji tiap-tiap seri konsentrasi dimasukkan ke dalam tabung reaksi bertutup dan ditambahkan 2,0 mL DPPH $40 \mu \mathrm{g} / \mathrm{mL}$, divorteks selama 1 menit hingga campuran homogen dan didiamkan selama 30 menit. Larutan ini kemudian diukur absorbansinya pada panjang gelombang $514 \mathrm{~nm}$ yg didapatkan dari uji pendahuluan . Dilakukan pula pembacaan absorbansi kontrol negatif yaitu tanpa penambahan larutan uji. Besarnya aktivitas antioksidan dihitung dengan menggunakan rumus:

$$
(\%)=\frac{(\text { Abs. kontrol }- \text { Abs. sampel })}{\text { Abs kontrol }} \times 100 \%
$$

Data absorbansi yang diperoleh dibuat persamaan regresi linear yang menyatakan hubungan antara konsentrasi bahan uji (x) dengan aktivitas antioksidan rata-rata (y) dari suatu seri replikasi pengukuran sehingga diperoleh harga IC50 yaitu konsentrasi bahan uji yang diperlukan untuk menangkap 50\% radikal DPPH selama 30 menit (operating time), atau jeda waktu yang dibutuhkan oleh bahan uji untuk mereduksi radikal DPPH dengan sempurna. 


\section{HASIL DAN PEMBAHASAN}

Ekstrak etanol 96\% temu kunci yang diperoleh dari proses ekstraksi dengan metode maserasi menghasilkan rendemen ekstrak sebanyak g. Hasil uji kualitatif dari identifikasi komponen fitokimia ekstrak etanol dan fraksi temu kunci sebagai berikut:

Tabel 1. Identifikasi Gologan Metabolit Sekunder

\begin{tabular}{|c|c|c|c|c|c|}
\hline \multirow[b]{2}{*}{$\begin{array}{l}\text { Metabolit } \\
\text { Sekunder }\end{array}$} & \multirow[b]{2}{*}{ Pereaksi } & \multicolumn{3}{|l|}{ Hasil } & \multirow[b]{2}{*}{ Reaksi Positif } \\
\hline & & $\begin{array}{l}\text { Ekstrak } \\
\text { Etanol 96\% }\end{array}$ & $\begin{array}{l}\text { Fraksi } \\
\text { EtOAc }\end{array}$ & $\begin{array}{l}\text { Fraksi } \\
\text { n-Heksan }\end{array}$ & \\
\hline Flavonoid & $\mathrm{HCl}+$ serbuk $\mathrm{Mg}$ & + & + & + & Larutan merah tua \\
\hline Polifenol & $\mathrm{FeCl}_{3} 10 \%$ & + & + & + & $\begin{array}{c}\text { Larutan } \\
\text { biru/hijau/hitam }\end{array}$ \\
\hline Alkaloid & Meyer & - & - & - & Endapan putih \\
\hline Alкаıола & Dragendorff & - & - & - & Endapan jigga \\
\hline Steroid & $\begin{array}{l}\text { Liberman- } \\
\text { Burchard }\end{array}$ & - & - & - & Cincin kebiruan/coklat \\
\hline
\end{tabular}

Keterangan : (+) positif

$(-)$ negatif

Berdasarkan identifikasi fitokimia ekstrak dan fraksi temu kunci yang terdapat pada Tabel 1 menunjukkan bahwa sampel mengandung senyawa flavonoid dan polifenol yang memiliki potensi aktivitas antioksidan. Hasil positif mengandung senyawa flavonoid ditunjukkan dengan adanya perubahan warna larutan menjadi merah tua. Warna merah tua pada larutan disebabkan terbentuknya garam flavilium (Achmad,1986). Identifikasi golongan senyawa polifenol dengan penambahan pereaksi $\mathrm{FeCl}_{3}$ pada sampel uji menimbulkan perubahan warna menjadi larutan hitam yang menandakan sampel uji positif mengandung senayawa polifenol. Hasil uji polifenol ditandai dengan terjadinya reaksi antara senyawa polifenol dan ferri klorida membentuk kompleks seyawa.

Uji aktivitas antioksidan ekstrak dan fraksi temu kunci dengan menggunakan metode DPPH untuk mengukur kemampuan suatu senyawa antioksidan dalam menangkap radikal bebas. Kemampuan penangkapan radikal berhubungan dengan kemampuan komponen senyawa dalam menyumbangkan elektron atau hidrogen. Setiap molekul yang dapat menyumbangkan elektron atau hidrogen akan bereaksi dan akan memudarkan DPPH. Intensitas warna DPPH akan berubah dari ungu menjadi kuning oleh elektron yang berasal dari senyawa antioksidan. Konsentrasi DPPH pada akhir reaksi tergantung pada konsentrasi awal dan struktur komponen senyawa penangkap radikal (Naik dkk., 2003).

Tabel 2.\%Aktivitas Peredaman Radikal DPPH

\begin{tabular}{ccc}
\hline Sampel & ${\text { Nilai } \mathbf{I C}_{\mathbf{5 0}}(\mu \mathrm{g} / \mathrm{mL})}^{\text {Kategori Daya Antioksidan }}$ \\
\hline Ekstrak Etanol & 112,342 & Sedang \\
Fraksi Etil Asetat & 162,224 & Lemah \\
Fraksi n-Heksan & 164,006 & Lemah \\
\hline
\end{tabular}

Menurut Jun dkk, (2003) tingkat kekuatan antioksidan adalah kuat $\left(\mathrm{IC}_{50}<50 \mathrm{ppm}\right)$, aktif ( $\mathrm{IC}_{50} 50-100 \mathrm{ppm}$ ), sedang ( $\mathrm{IC}_{50}$ 101-250), lemah (IC I0 $_{50}$ 250-500) dan tidak aktif (IC 50 $>500 \mathrm{ppm})$. Nilai aktivitas antioksidan ekstrak etanol $96 \%$ temu kunci memiliki nilai $\mathrm{IC}_{50}$ yang lebih kecil kadarnya dibandingkan dengan nilai $\mathrm{IC}_{50}$ dari fraksi etil asetat dan $\mathrm{n}$ - 
heksan namun dalam penggologan kategori kekuatan antioksidan, ekstrak etanol $96 \%$ temu kunci masuk dalam kategori sedang. Aktivitas antioksidan yang lebih tinggi pada ekstrak etanol 96\% temu kunci dibandingkan dengan fraksinya memungkinkan adannya sinergi antar senyawa-senyawa berpotensi sebagai antioksidan yang apabila dilakukan fraksinasi maka senyawa-senyawa tersebut berkurang aktivitasnya.

\section{KESIMPULAN}

Temu kunci memiliki kandungan senyawa-senyawa antioksidan seperti polifenol dan flavonoid yang dapat dimaanfaatkan secara luas dibidang kesehatan. Dengan konsentrasi hambat radikal bebas yang cukup kecil dimiliki oleh ekstrak temu kunci yaitu 112,342 ppm dan fraksi etil asetat 162,224 ppm serta fraksi n-heksan 164,006 ppm berpotensi untuk dimanfaatkan secara luas sebagai bahan kefarmasian.

\section{SARAN}

Diperlukan penelitian lanjutan untuk tingkatan fraksinasi hingga isolasi senyawa. Serta upaya dalam pegujian aktivitas dan pengembangan formulasi sediaan yang berasal dari senyawa aktif yang terkandung dalam rimpng temu kunci.

\section{DAFTAR PUSTAKA}

Achmad, S.A. Kimia Organik Bahan Alam. Karnunika, Jakarta.1986

Ardie, Ari Muhandari. 2011. Radikal Bebas dan Peran Antioksidan dalam Mencegah Penuaan. Medicinus 24(1).

Buhler, D.R., and Miranda, C., 2000, Antioxidant activities of Flavonoid, Department of Enviromental and Molecular Toxicology Oregon State University, Oregon.

Hudson, B. J. F, 1990, Food Antioxidants, Elsevier Applied Science, New York.

Jun, M.H.Y., J., Fong, X., Wan, C.S., Yang, C.T., Ho. 2003. Camparison of Antioxidant Activities of Isoflavones Form Kudzu Root (Puerarua labata O). Journal Food Science Institute of Technologist. 68:2117-2122.

Naik, G.H., Priyadarsini, K.I., Satav, J.G., Banavalikar, M.M., Sohoni, D.P., Biyani, M.K., and Mohan H., 2003, Comparative antioxidant activity of individual herbal components used in ayurvedic medicine, Phytochemistry, 63 (1): 97-104

Syamsuhidayat, S. S., Hutapea, J.R., 1991, Inventaris Tanaman Obat Indonesia I, Depkes RI, Jakarta, 92-93.

Winarsi, H. 2007. Antioksidan Alami dan Radikal Bebas Potensi dan Aplikasi dalam Kesehatan. Kanisius: Yogyakarta.

Zheng W, Wang SY. 2001. Antioxidant Activity and Phenolic Compounds in Selected Herbs. J Agric Food Chem 49:5165-5170. 